\title{
Studi Numerikal Tekuk Web pada Balok Baja Kastela Akibat Kombinasi Momen Lentur dan Gaya Geser
}

\author{
William Wiranata ${ }^{1, *}$, Paulus Karta Wijaya ${ }^{1}$ \\ Program Studi Magister Teknik Sipil, Universitas Katolik Parahyangan, Bandung ${ }^{1}$ \\ Koresponden*, Email: 8101801022@student.unpar.ac.id
}

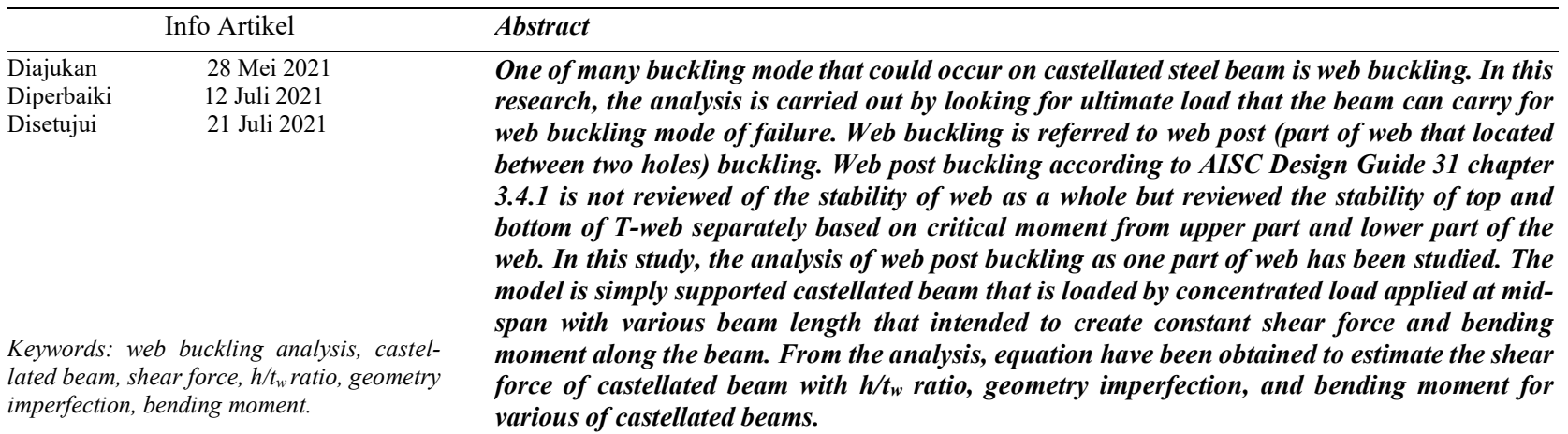

\begin{abstract}
Abstrak
Salah satu ragam tekuk yang terjadi pada balok baja kastela adalah tekuk pada web penampang. Dalam penelitian ini, analisis dilakukan untuk mencari besarnya beban ultimit yang dapat dipikul balok untuk ragam kegagalan tekuk web. Tekuk web yang dimaksud adalah tekuk pos web (bagian web yang terletak di antara bukaan web). Tekuk pos web menurut AISC Design Guide 31 pasal 3.4.1 tidak meninjau kestabilan web secara keseluruhan tetapi meninjau stabilitas pelat $T$-web atas dan bawah secara terpisah berdasarkan momen kritis dari bagian atas atau bawah web. Pada studi ini, dilakukan analisis tekuk web balok kastela sebagai satu kesatuan. Model yang ditinjau adalah balok kastela yang terletak di atas dua tumpuan sederhana dengan berbagai ukuran panjang. Beban yang diberikan adalah beban terpusat di tengah bentang dengan maksud untuk menciptakan gaya geser konstan dan momen lentur bervariasi di sepanjang balok. Dari analisis tersebut diperoleh persamaan untuk memprediksi gaya geser kritis dengan parameter $h / t_{w}$, ketidaksempurnaan geometri, dan momen lentur untuk berbagai profil balok kastela.
\end{abstract}

Kata kunci: analisis tekuk web, balok kastela, gaya geser, rasio $\mathrm{h} / \mathrm{t}_{\mathrm{w}}$, ketidaksempurnaan geometri, momen lentur. kastela terhadap defleksi dan ragam kegagalan yang terjadi. Dari hasil penelitian tersebut menunjukkan bahwa balok baja kastela mencapai kondisi paling efisien dalam memenuhi kondisi layan pada saat bukaan web sebesar 0,6 kali tinggi total balok [1].

M.R. Soltani, A. Bouchair, dan M. Mimoune melakukan penelitian dengan model numerikal yang terdiri dari 2 model balok kastela yang memiliki bukaan heksagonal dan oktagonal. Penggunaan ketidaksempurnaan geometri didapatkan dari analisis eigenvalues buckling sebesar h/100 sampai h/200 berdasarkan ENV1993-1-1 Eurocode 3: Design of Steel Structures Annex N [2]. Variabel h adalah tinggi bersih web balok kastela. Studi parameter ini dilakukan dengan membandingkan ultimate load behavior dari balok baja kastela heksagonal maupun oktagonal yang ditujukan terhadap momen lentur dan gaya geser [3]. 
Hao Deng, WanLi Pu, TongLin Li, dan Danyang Chen melakukan penelitian mengenai perilaku tekuk web balok kastela dengan pengaku transversal terhadap beban merata dengan menggunakan program ANSYS 15.0. Dari hasil penelitian yang dilakukan menunjukkan bahwa adanya stiffener dapat meningkatkan beban kritis balok kastela [4].

Studi penelitian yang dilakukan oleh P. Pourbehi dan A. Pirmoz bertujuan untuk mengetahui kegagalan tekuk pos web akibat respon geser. Pada penelitian ini, penggunaan bentang pendek pada balok baja kastela menghasilkan deformasi yang besar dan respon geser yang dominan pada web [5].

F. Menkulasi, C. D. Moen, M. R. Eatherton, dan D. Kuruppuarachchi telah melakukan penelitian mengenai batas tekuk kompresi pos web dan kebutuhan pengaku pada balok baja kastela yang bertujuan untuk menginvestigasi batas limit dari web post buckling terhadap beban merata sebagian dan menguantifikasikan kapasitas dari web post ketika stiffener diberikan. Dari hasil analisis yang dilakukan menunjukkan bahwa semakin tinggi penampang web pada balok baja kastela tanpa stiffener maka pengaruh kelangsingan web semakin jelas berpengaruh terhadap tekuk pada web baja kastela [6].

Wenting Ji, Lianguang Jia, Yuhan Wang, dan Chen Chen telah melakukan penelitian eksperimental mengenai tekuk lokal pada balok baja kastela akibat lentur murni yang bertujuan untuk menginvestigasi kinerja tekuk dari tiga baja kastela yang disertai perbedaan rasio tinggi dengan tebal web dan stiffener diuji terhadap lentur murni. Dari studi eksperimental ini dapat disimpulkan bahwa mereduksi rasio tinggi web terhadap tebal web dan mengatur letak stiffener dapat meningkatkan kinerja tekuk web dari baja kastela, tetapi bukaan pada pelat web dapat melemahkan kapasitas web [7].

Pada studi ini, akan dibahas mengenai perilaku tekuk pada web balok kastela. Balok kastela dimodelkan di atas dua perletakan sederhana. Pada tumpuan, rotasi puntir ditahan tetapi pilin (warping) tidak ditahan. Untuk mencegah terjadinya tekuk torsi lateral, dipasang bresing lateral dalam jarak yang cukup. Pengaruh kekakuan flens tidak ditinjau dalam studi ini. Pembebanan dilakukan secara terpusat pada stiffener di tengah bentang balok seperti terlihat pada Gambar 1. Metodologi yang digunakan adalah analisis keruntuhan dengan metode elemen hingga yaitu dengan bantuan perangkat lunak ADINA 9.5. Variasi yang digunakan dalam penelitian ini adalah tebal web, panjang bentang balok, dan ketidaksempurnaan geometri. Parameter geometri lubang dibuat tetap yaitu menggunakan geometri dari tabel penampang Gunung Garuda. Pada penelitian ini, perilaku tekuk web ditinjau dari segi hubungan gaya geser kritis terhadap rasio $\mathrm{h} / \mathrm{t}_{\mathrm{w}}$, ketidaksempurnaan geometri, dan besar momen lentur yang terjadi pada balok kastela. Setelah itu, hasilnya dibandingkan dengan gaya geser kritis menurut AISC Design Guide.

Tekuk pada bagian pos web baja kastela menurut AISC Design Guide nomor 31 pasal 3.4.1 tidak meninjau kestabilan web secara keseluruhan tetapi meninjau stabilitas pelat $\mathrm{T}$ web atas dan bawah secara terpisah berdasarkan momen kritis dari bagian atas atau bawah web [8] sehingga belum adanya tinjauan web baja kastela sebagai satu kesatuan pelat tanpa memisahkan pelat T-web atas dan bawah. Tekuk pos web pada balok baja kastela menurut AISC Design Guide dapat diilustrasikan sesuai dengan Gambar 2. Yang dimaksud dengan pos web adalah bagian web yang terletak di antara dua lubang. Kekuatan tekuk pos web berdasarkan design guide tersebut dihitung dengan meninjau free body setengah pos web dengan adanya gaya geser horizontal yang melewati tengah-tengah pos web. Kemudian dengan suatu persamaan dihitung gaya geser kritis pada setengah pos web tersebut. Oleh karena itu, perlu dilakukan tinjauan stabilitas web sebagai satu kesatuan pelat akibat gaya geser dan momen lentur. Konfigurasi lubang balok kastela mengikuti konfigurasi produk Gunung Garuda sehingga konfigurasi lubang tidak divariasikan. Parameter yang ditinjau adalah rasio tinggi bersih web terhadap tebal web, panjang bentang balok, dan ketidaksempurnaan geometri.

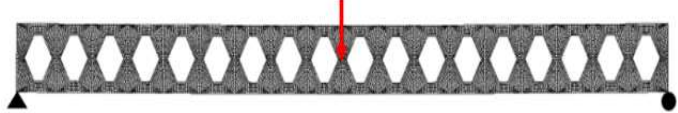

Gambar 1. Model Balok Baja Kastela di atas Tumpuan Sederhana dengan Pembebanan Terpusat di Tengah Bentang

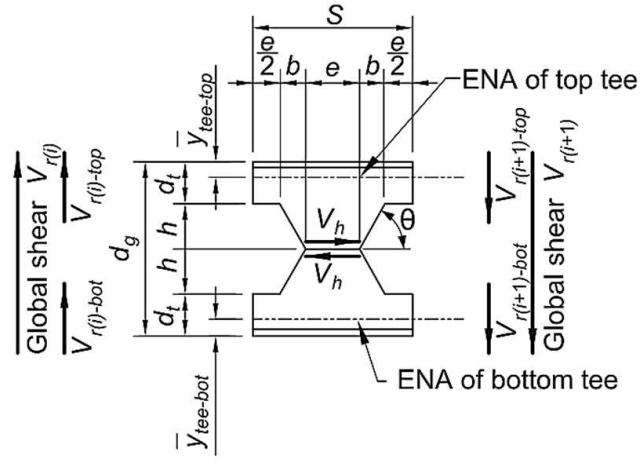

Gambar 2. Gaya Geser Horizontal dan Vertikal yang Bekerja pada Balok Baja Kastela [8]

\section{Pemodelan Elemen Hingga}

Pemodelan elemen hingga dilakukan dengan menggunakan perangkat lunak ADINA 9.5, di mana analisis dilakukan dengan menggunakan analisis keruntuhan (collapse analysis) 
pada model yang mempunyai ketidaksempurnaan geometri. Tipe elemen yang digunakan pada penelitian adalah elemen cangkang (shell). Diskritisasi ukuran elemen dilakukan pada setiap bagian web, flens, dan stiffener, serta mesh refirement dengan ukuran elemen lebih kecil dilakukan pada tepi bukaan web baja kastela. Analisis dilakukan secara kontrol perpindahan hingga balok mengalami keruntuhan. Analisis dilakukan dengan menggunakan teori deformasi besar (large deformation). Sebelum analisis keruntuhan dilakukan, terlebih dahulu dilakukan analisis tekuk linier untuk mendapatkan ragam tekuk pertama. Ragam tekuk pertama ini digunakan untuk mendefinisikan distribusi ketidaksempurnaan geometri dari model elemen hingga. Besarnya ketidaksempurnaan geometri yang terbesar diambil berkisar antara $\mathrm{h} / 100$ sampai $\mathrm{h} / 200$ [3]. Variabel h yang dimaksud adalah tinggi bersih web balok kastela. Dalam studi ini, ketidaksempurnaan geometri yang terbesar diambil sama dengan 1, 2, 3, dan $4 \mathrm{~mm}$ dengan arah tegak lurus bidang web.

Material yang digunakan dalam penelitian ini adalah material baja dengan tegangan leleh $250 \mathrm{MPa}$. Hubungan tegangan-regangan yang digunakan adalah plastic multilinear. Hubungan tersebut dapat dilihat pada Gambar 3. Modulus elastisitas yang digunakan adalah $200 \mathrm{GPa}$ dan rasio Poisson 0,3. Seluruh bagian balok diasumsikan perfectly bonded sehingga las tidak dimodelkan. Profil balok yang digunakan dalam studi ini adalah HC 450x300x10x15 dan HC 600x200x8x13 dengan variasi ketebalan web, bentang balok $\left(\mathrm{L}_{\mathrm{b}}\right)$, dan geometri imperfection seperti terlampir pada Tabel 1 dan Tabel 2. Ilustrasi geometri balok kastela yang dimodelkan dan notasi yang digunakan ditampilkan pada

\section{Gambar 4.}

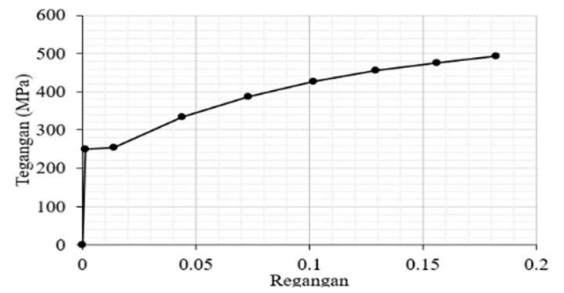

Gambar 3. Kurva Tegangan-Regangan Plastic Multilinear

Untuk kondisi batas, pada salah satu ujung balok, semua titik nodal perpindahannya ditahan di arah $\mathrm{x}$ dan $\mathrm{z}$ kecuali titik nodal yang terletak pada sumbu $\mathrm{x}$ ditahan di arah $\mathrm{x}, \mathrm{y}$, dan z. Pada ujung yang lain, semua titik nodal perpindahannya ditahan di $\operatorname{arah} \mathrm{x}$ dan $\mathrm{z}\left(\mathrm{u}_{\mathrm{x}}=\mathrm{u}_{\mathrm{z}}=0\right)$. Untuk mencegah terjadinya tekuk torsi lateral, semua titik pada tengah flens atas dan flens bawah, perpindahan di arah $\mathrm{x}$ ditahan $\left(\mathrm{u}_{\mathrm{x}}=0\right)$. Sebagai contoh, kondisi batas salah satu ujung balok kastela adalah seperti diperlihatkan pada Gambar 5. Pada ujung balok dan tengah bentang dipasang pengaku transversal.
Beban terpusat diberikan berupa beban vertikal ke bawah pada titik nodal di pengaku transversal tengah bentang yang terletak pada garis melalui pusat penampang dan sejajar sumbu x. Beban tersebut bekerja tepat pada sumbu vertikal balok sehingga tidak ada eksentrisitas pada beban yang diberikan.

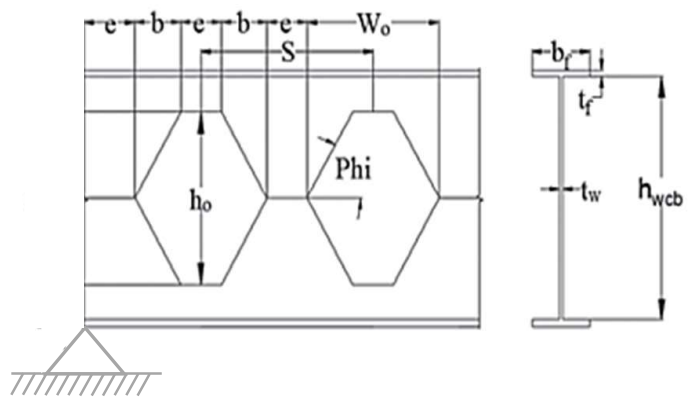

Gambar 4. Sketsa Geometri Balok Kastela

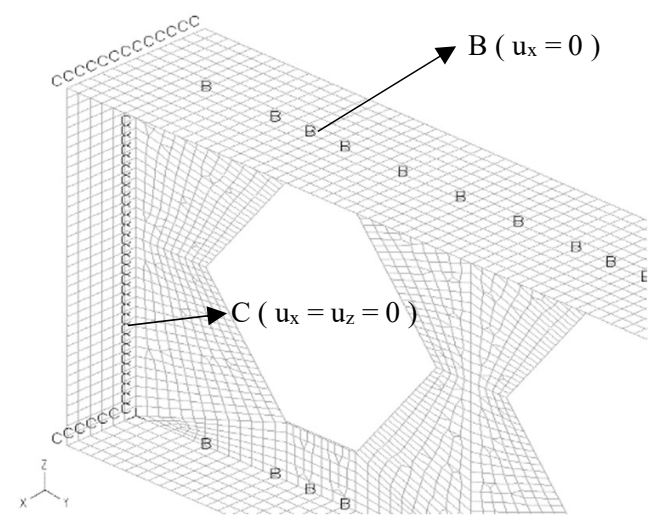

Gambar 5. Kondisi Batas untuk salah satu ujung Balok Kastela

\section{Hasil dan Pembahasan}

Analisis keruntuhan (collapse analysis) dilakukan untuk mencari beban ultimit dan mengetahui bentuk tekuk yang terjadi pada web balok kastela seperti yang terlihat pada Gambar 6. Beban ultimit dapat ditentukan dari kurva beban defleksi. Dari hasil analisis dibuat kurva gaya geser terhadap perpindahan lateral. Kurva tersebut dapat mempunyai titik maksimum. Akan tetapi, kurva tersebut juga dapat berupa kurva yang asimtotik. Bila kurva bersifat asimtotik maka gaya geser ultimit diambil sebesar nilai asimtotnya. Dari hasil analisis keruntuhan menggunakan ADINA 9.5, beban ultimit diperoleh dari kurva hubungan antara peralihan lateral dan gaya geser untuk profil HC 600x200 yang ditampilkan pada Gambar 7. Sedangkan kurva hubungan antara peralihan lateral dan gaya geser untuk profil HC 450x300 ditampilkan pada Gambar 8. Pada kedua gambar kurva tersebut, beban ultimit adalah dua kalinya gaya geser kritis yang merupakan 
Tabel 1. Variasi Bentang Balok dan Ukuran Dimensi Bukaan HC 600x200

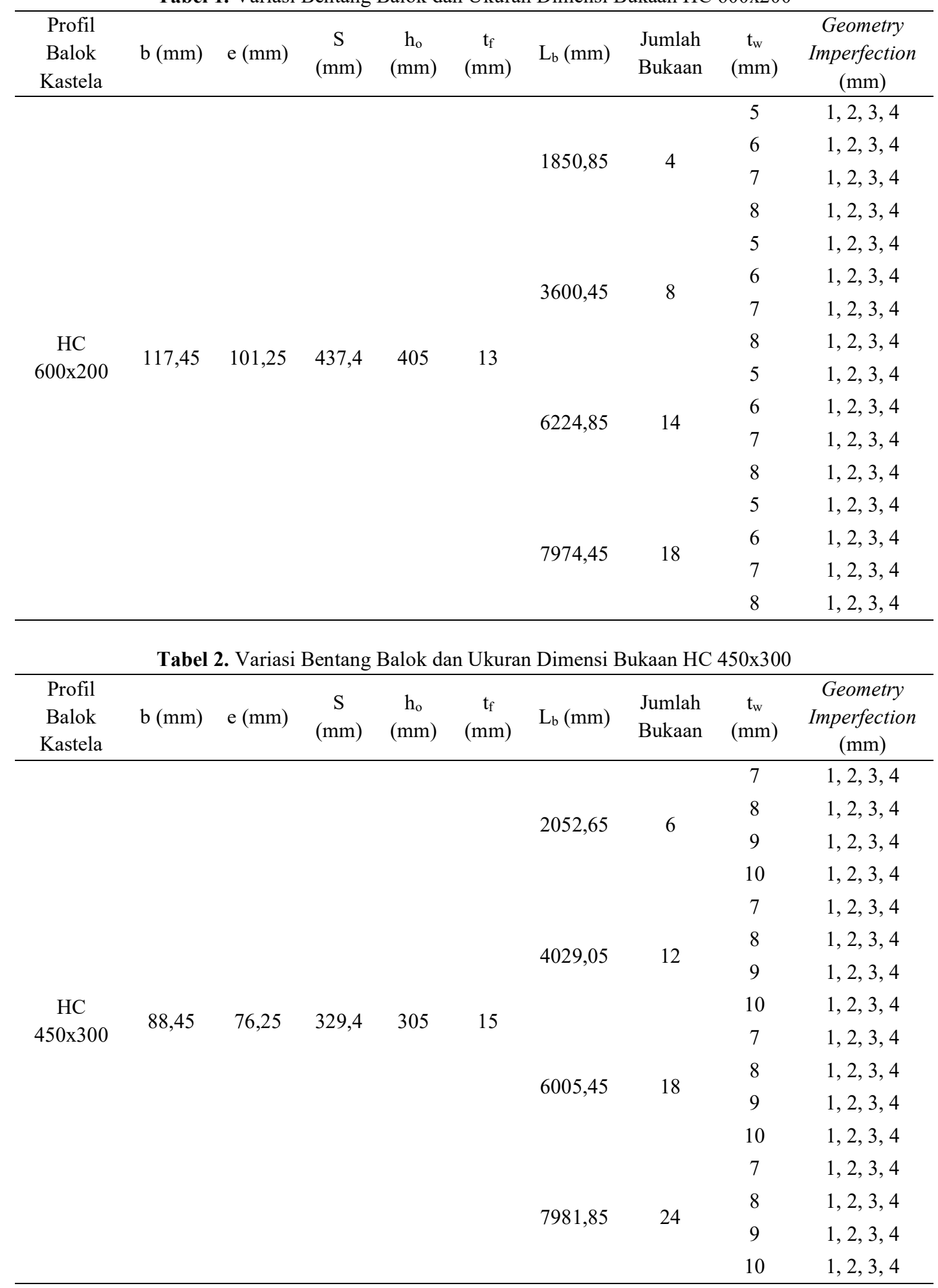


beban puncak dari kurva beban defleksi sebelum mengalami penurunan kurva. Indeks nama yang digunakan pada kedua gambar kurva tersebut adalah seperti contoh HCW8L2_G4. Indeks tersebut menjelaskan bahwa balok baja kastela memiliki tebal web sebesar $8 \mathrm{~mm}$, panjang bentang sebesar 2 meter, dan geometri imperfection sebesar $4 \mathrm{~mm}$. Pemberian nama pada indeks grafik tersebut digunakan untuk setiap profil balok HC 600x200 dan HC 450x300.

Perilaku tekuk web pada balok kastela juga dapat ditinjau dari grafik hubungan antara gaya geser ultimit dengan panjang bentang balok kastela. Hubungan antara gaya geser ultimit terhadap panjang bentang untuk balok HC 600x200 dapat dilihat pada Gambar 9. Balok kastela HC 600x200 dengan panjang bentang 2 meter dapat memikul gaya geser paling besar daripada balok kastela dengan panjang bentang lainnya. Perilaku tekuk web tersebut juga berlaku pada balok kastela HC 450x300 dengan panjang bentang 2 meter. Perilaku tersebut dapat dilihat dari grafik hubungan antara gaya geser ultimit dan panjang bentang balok pada Gambar 10. Oleh karena itu, dapat disimpulkan bahwa semakin pendek balok kastela maka semakin besar nilai gaya geser yang dapat diterima balok dengan ketidaksempurnaan geometri yang sama. Namun, semakin panjang bentang balok yang direncanakan maka semakin kecil gaya geser yang dapat dipikul oleh balok kastela. Hal ini terjadi karena adanya kombinasi momen lentur dan gaya geser yang terjadi pada balok
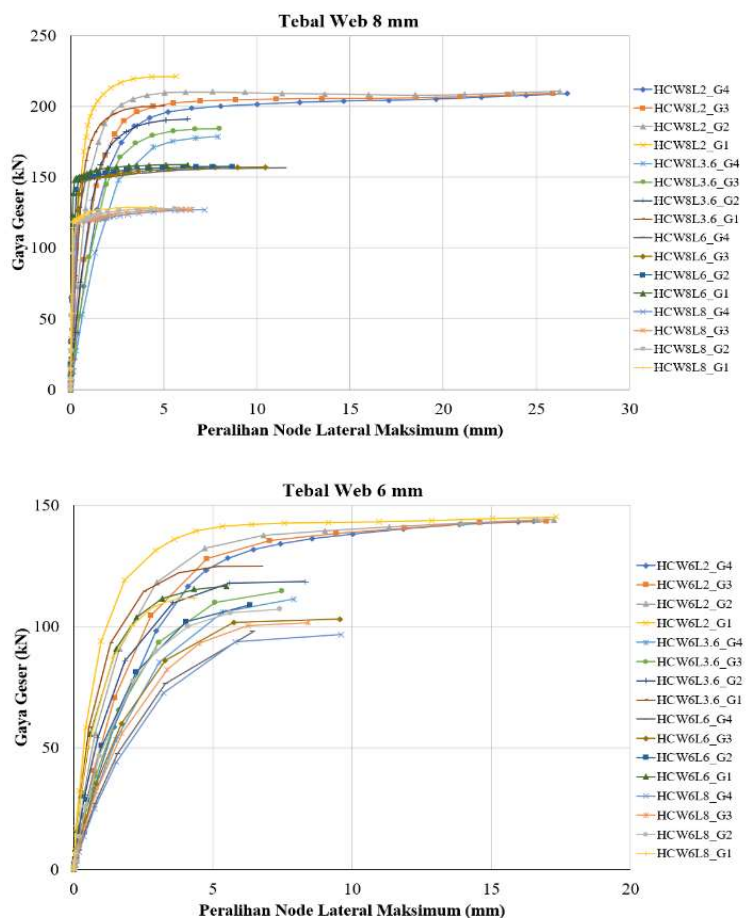

Gambar 7. Kurva Hubungan Gaya Geser dan Peralihan Lateral Balok Kastela HC 600x200 untuk tebal web 8, 7, 6, dan 5 mm

kastela dengan bentang panjang akibat beban terpusat di tengah bentang.

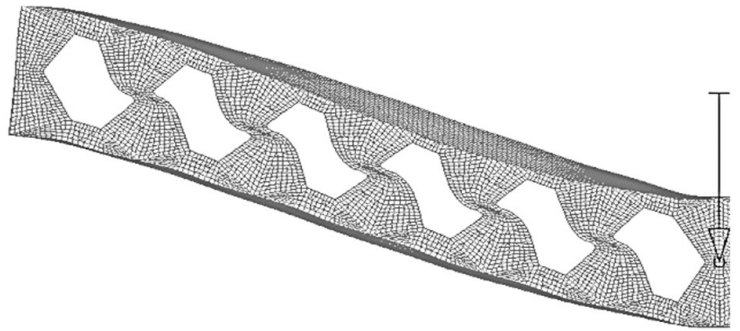

Gambar 6. Bentuk Tekuk Web Balok Kastela Berdasarkan Analisis Keruntuhan

Perilaku tekuk web juga dapat dilihat pada hubungan antara gaya geser ultimit dan geometri imperfection (ketidaksempurnaan geometri). Dalam penelitian ini, nilai ketidaksempurnaan geometri yang terbesar diambil sama dengan 1 , 2, 3, dan $4 \mathrm{~mm}$ dengan arah tegak lurus bidang web. Hasil gaya geser yang diperoleh setiap bentang balok mengalami penurunan pada setiap penambahan besarnya ketidaksempurnaan geometri. Hal ini dibuktikan dengan semakin besarnya nilai ketidaksempurnaan geometri maka semakin kecil nilai gaya geser kritis yang dapat diterima balok kastela HC 600x200 dan HC 450x300. Distribusi ketidaksempurnaan geometri didefinisikan dari ragam tekuk pertama (first buckling mode) berdasarkan analisis tekuk linier pada web balok kastela.
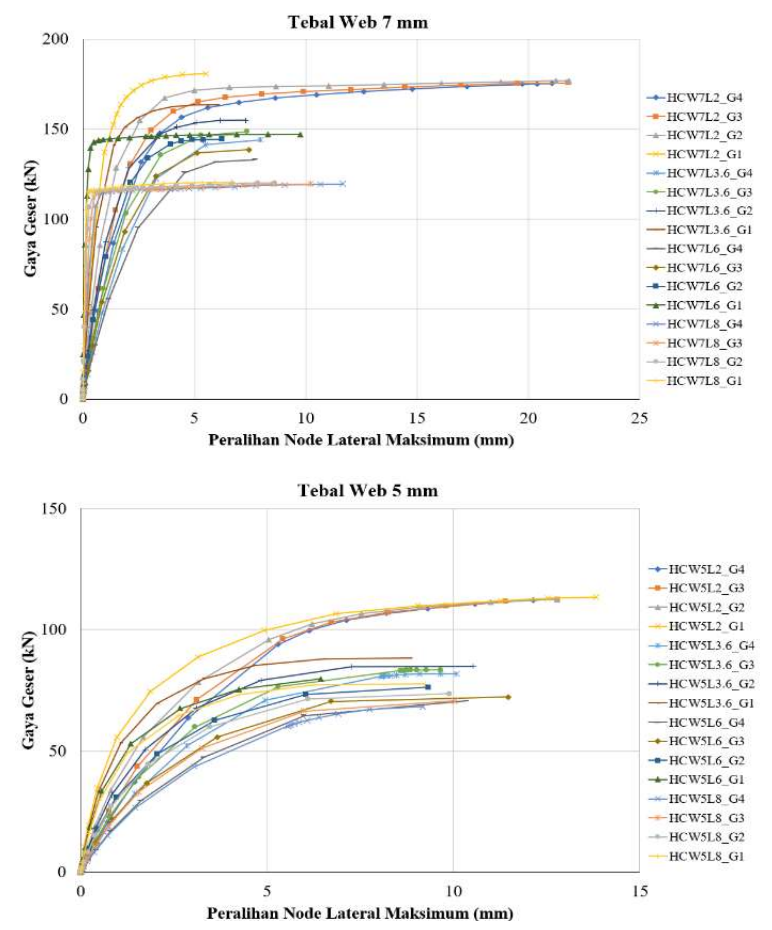

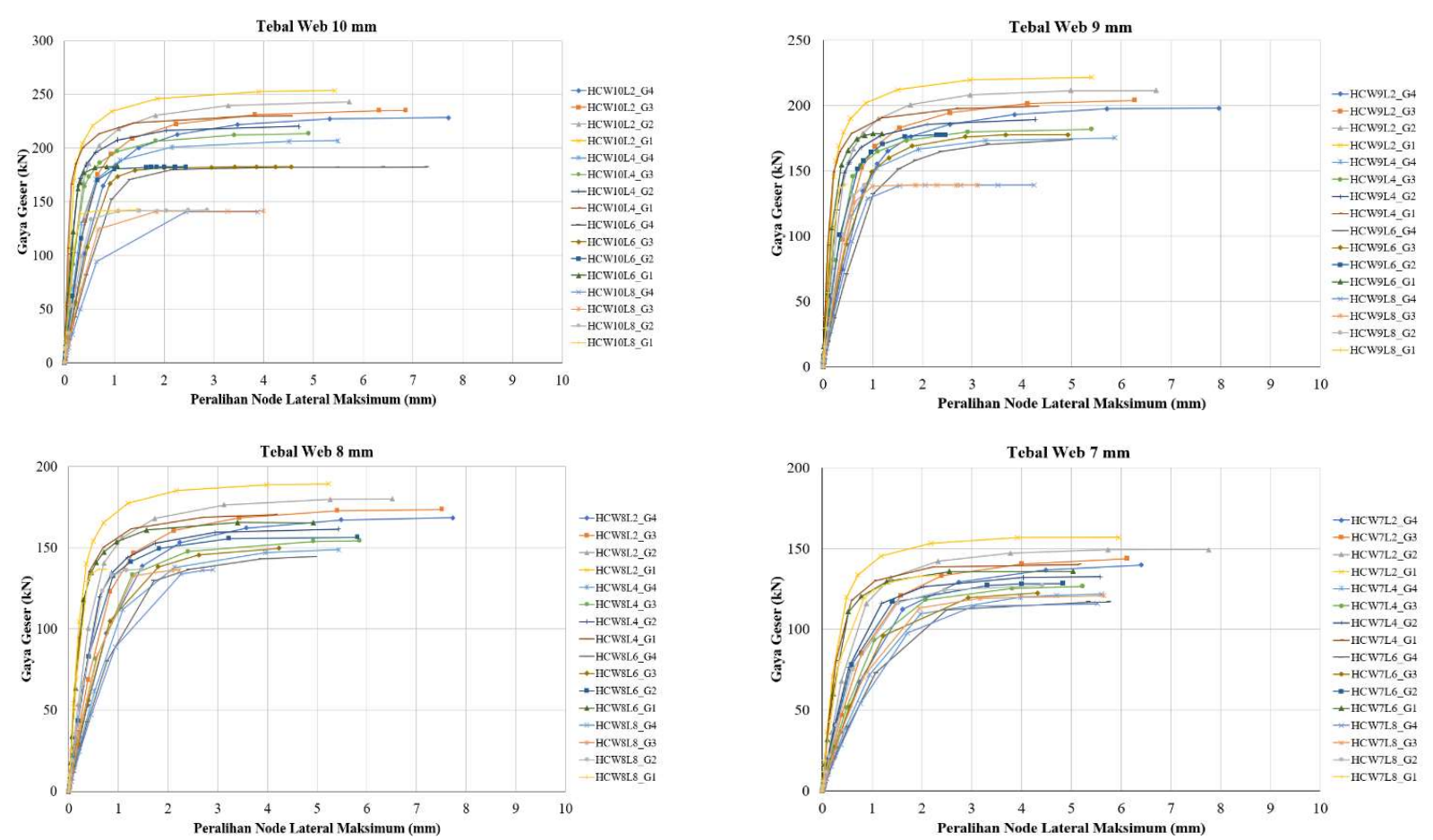

Gambar 8. Kurva Hubungan Gaya Geser dan Peralihan Lateral Balok Kastela HC 450x300 untuk tebal web 10, 9, 8, dan 7 $\mathrm{mm}$
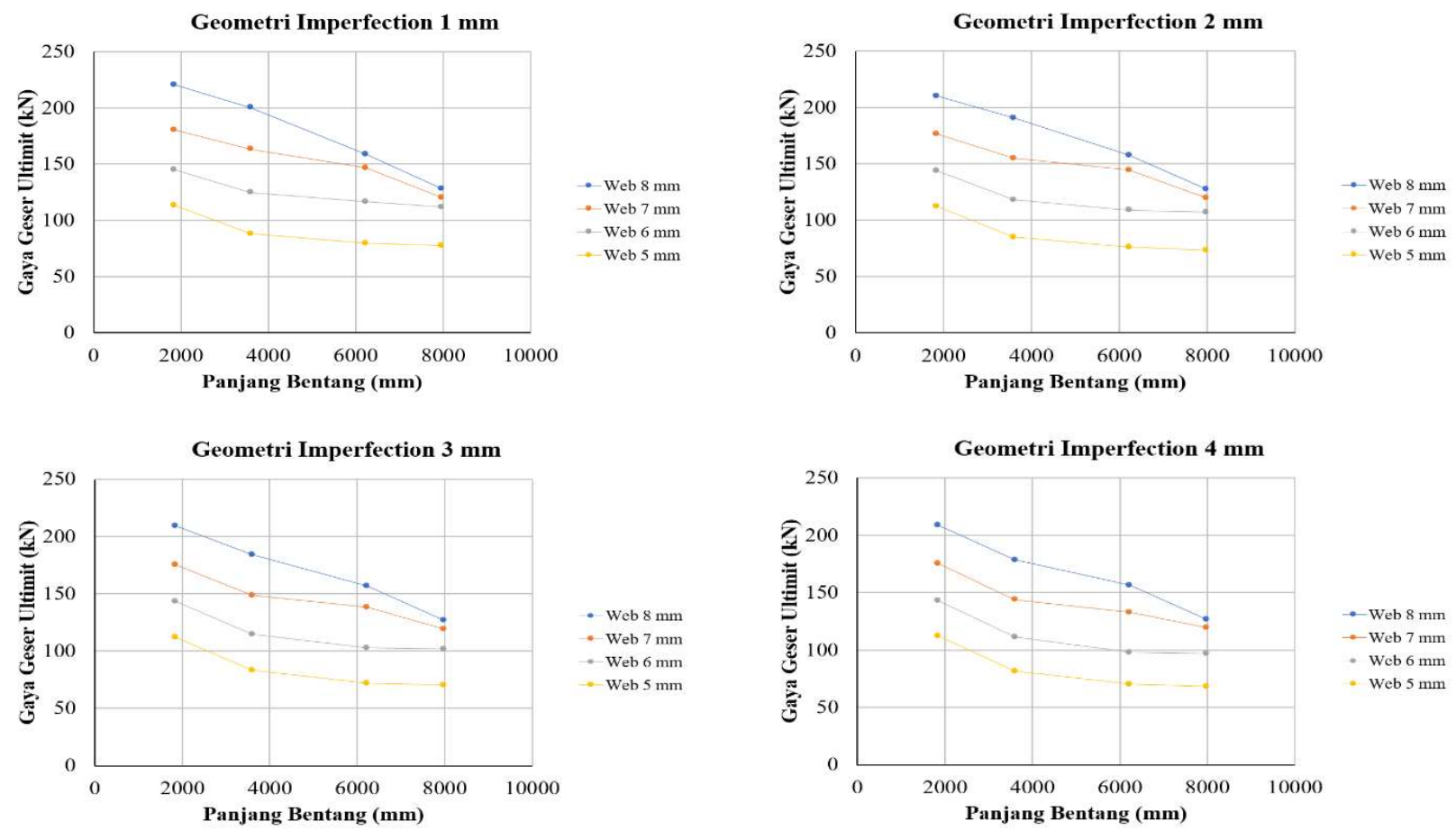

Gambar 9. Grafik Hubungan Gaya Geser Ultimit dan Panjang Bentang Balok Kastela HC 600x200 untuk Geometri Imperfection 1, 2, 3, dan $4 \mathrm{~mm}$ 

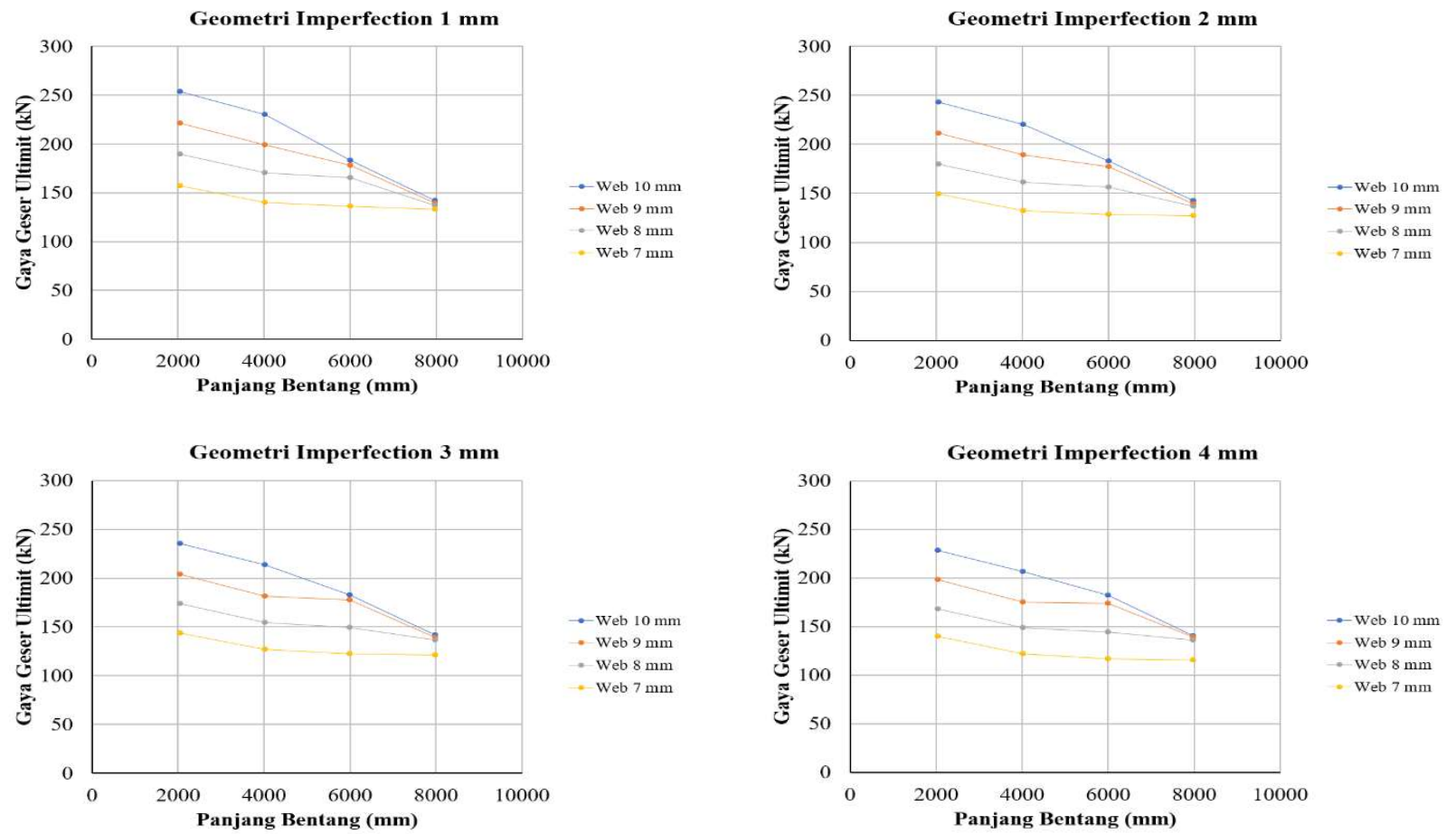

Gambar 10. Grafik Hubungan Gaya Geser Ultimit dan Panjang Bentang Balok Kastela HC 450x300 untuk Geometri

Imperfection 1, 2, 3, dan $4 \mathrm{~mm}$

Selanjutnya ditinjau pengaruh momen lentur terhadap gaya geser kritis. Momen lentur maksimum dihitung berdasarkan panjang bentang balok kastela sehingga panjang balok dinyatakan dalam bentuk momen lentur. Oleh karena itu, parameter yang digunakan dalam mencari persamaan gaya geser kritis antara lain momen lentur yang mewakili panjang bentang balok kastela. Grafik hubungan antara momen lentur dan gaya geser ultimit untuk profil HC 600x200 dapat ditampilkan pada Gambar 11. Sedangkan grafik hubungan antara momen lentur dan gaya geser ultimit untuk profil HC 450x300 dapat ditampilkan pada Gambar 12.

Gaya geser kritis mengecil saat momen lentur membesar. Besarnya momen lentur balok kastela dengan profil balok HC 600x200 dan HC 450x300 memberikan pengaruh terhadap gaya geser kritis yang terjadi. Hal ini dibuktikan bahwa adanya momen lentur balok kastela dapat mengurangi gaya geser kritis yang dapat diterima balok kastela.

Semakin besar momen lentur yang terjadi maka semakin kecil gaya geser pada balok kastela. Oleh karena itu, tekuk web yang terjadi bukan hanya dipengaruhi oleh gaya geser melainkan juga dipengaruhi oleh momen lentur yang terjadi pada balok kastela.

Sebelum melakukan analisis regresi, perlu dianalisis terlebih dahulu kedua profil balok kastela untuk mengetahui pengaruh tebal web terhadap gaya geser. Hubungan antara rasio $\mathrm{h} / \mathrm{t}_{\mathrm{w}}$ dan gaya geser ultimit untuk profil HC 600x200 dapat ditampilkan pada Gambar 13. Sedangkan hubungan antara rasio $\mathrm{h} / \mathrm{t}_{\mathrm{w}}$ dan gaya geser ultimit untuk profil $\mathrm{HC}$ 450x300 dapat ditampilkan pada Gambar 14. Parameter panjang bentang, rasio $\mathrm{h} / \mathrm{t}_{\mathrm{w}}$, geometri imperfection, dan momen lentur yang mempengaruhi gaya geser pada balok kastela dapat dilihat pada Tabel 3 dan Tabel 4.

Dari tabel dan gambar grafik hubungan rasio $h / t_{\mathrm{w}}$ dan gaya geser ultimit untuk semua profil balok kastela menunjukkan bahwa semakin besar rasio $\mathrm{h} / \mathrm{t}_{\mathrm{w}}$ maka semakin kecil gaya geser yang diterima oleh balok baja kastela. Yang dimaksud $h$ adalah tinggi bersih web balok kastela dan $t_{w}$ adalah tebal web balok kastela. Grafik tersebut juga membuktikan bahwa semakin tebal web balok kastela maka semakin besar gaya geser yang dapat diterima akibat beban ultimit yang dipikul semakin besar. Hal ini mengindikasikan bahwa faktor rasio $\mathrm{h} / \mathrm{t}_{\mathrm{w}}$ merupakan faktor penting dalam menentukan besarnya nilai gaya geser seperti yang digunakan dalam persamaan AISC Specification chapter G section G2 dan G3. Pada persamaan AISC tersebut, rasio $\mathrm{h} / \mathrm{tw}$ digunakan untuk mencari nilai faktor $\mathrm{C}_{\mathrm{v}}$ (koefisien tekuk geser web) [9]. Dalam penelitian ini, koefisien $\mathrm{C}_{\mathrm{V}}$ kemudian dikoreksi menjadi koefisien kekuatan geser (C) yang dipengaruhi oleh momen lentur dan gaya geser. Oleh karena itu, rasio $\mathrm{h} / \mathrm{t}_{\mathrm{w}}$ digunakan sebagai variabel independen dalam analisis regresi terhadap gaya geser kritis pada profil balok kastela HC 600x200 dan HC 450x300. 

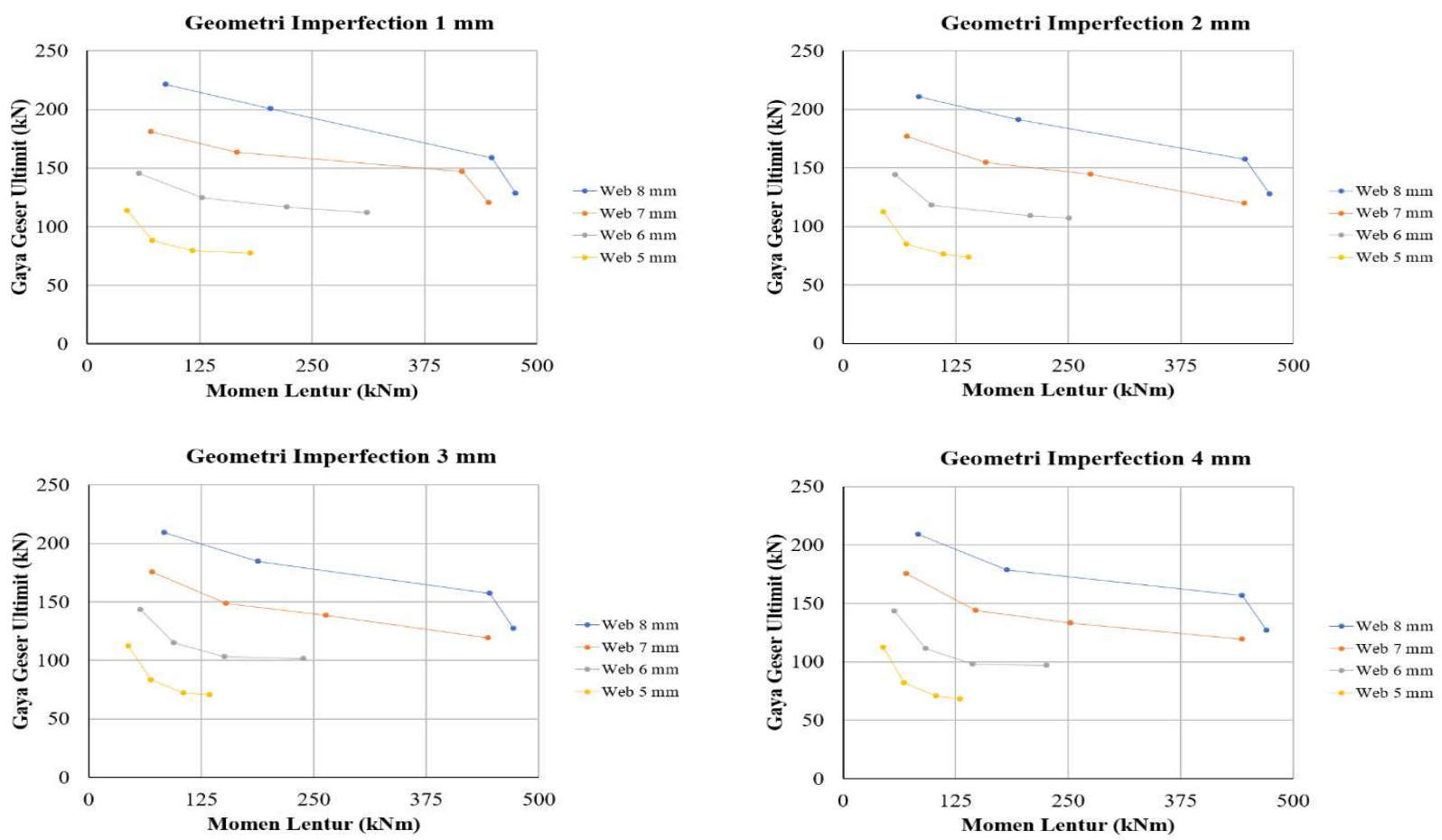

Gambar 11. Grafik Hubungan Gaya Geser Ultimit dan Momen Lentur Pada Balok Kastela HC 600x200 untuk Geometri Imperfection 1, 2, 3, dan $4 \mathrm{~mm}$
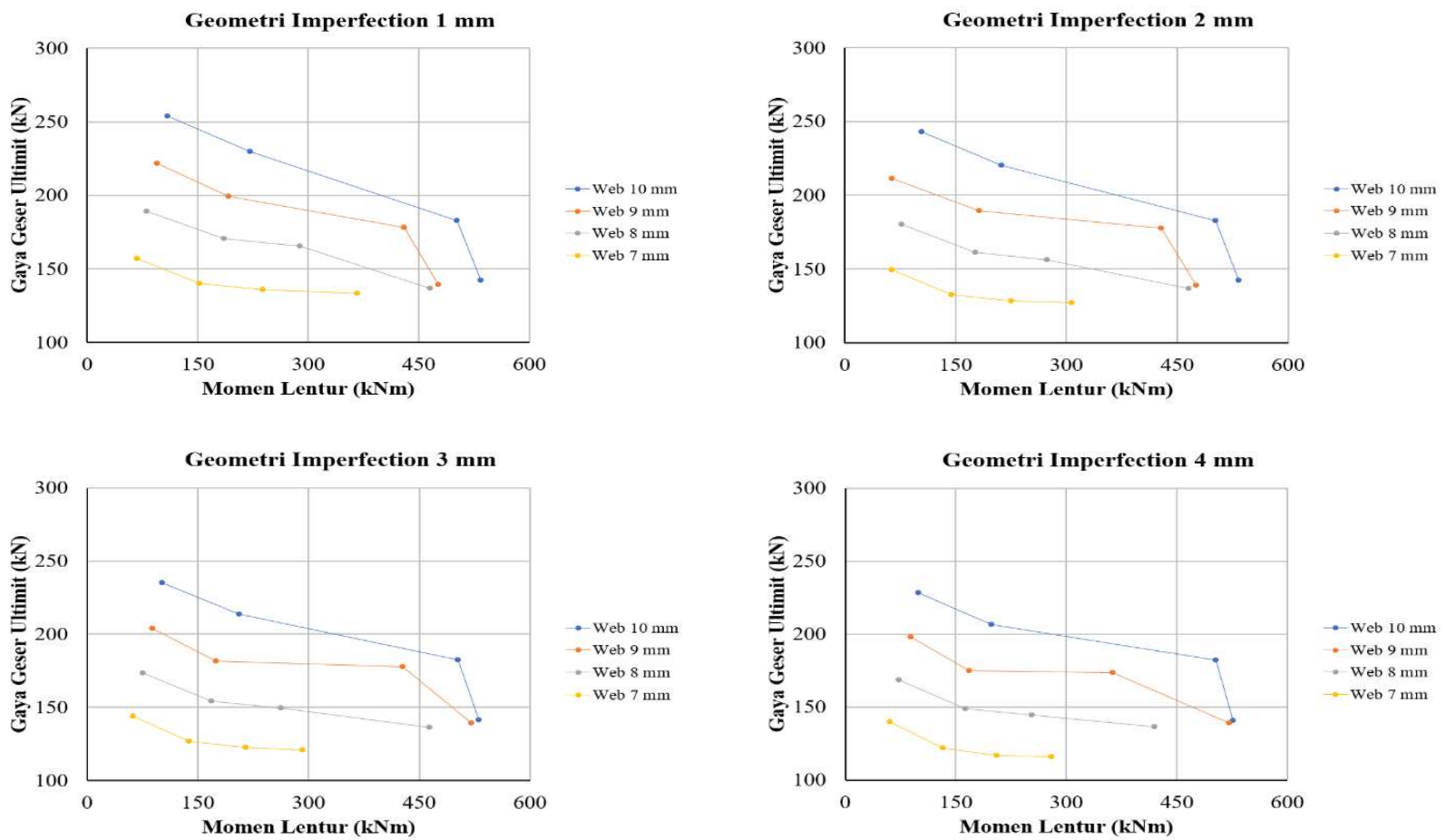

Gambar 12. Grafik Hubungan Gaya Geser Ultimit dan Momen Lentur Pada Balok Kastela HC 450x300 untuk Geometri Imperfection 1, 2, 3, dan $4 \mathrm{~mm}$ 

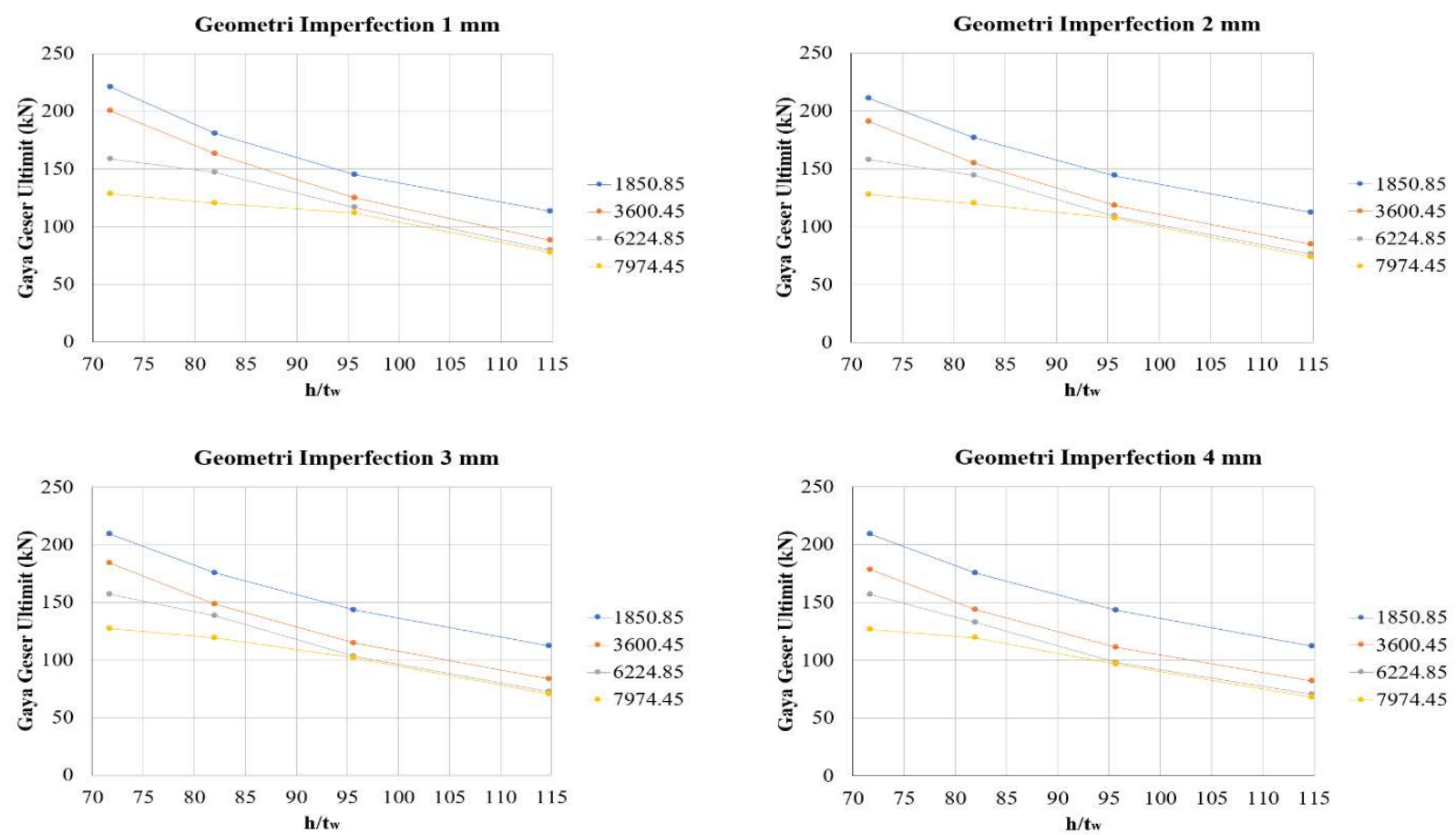

Gambar 13. Grafik Hubungan Gaya Geser Ultimit dan Rasio $h / t_{\mathrm{w}}$ pada Balok Kastela HC 600x200 untuk Geometri Imperfection 1, 2, 3, dan $4 \mathrm{~mm}$
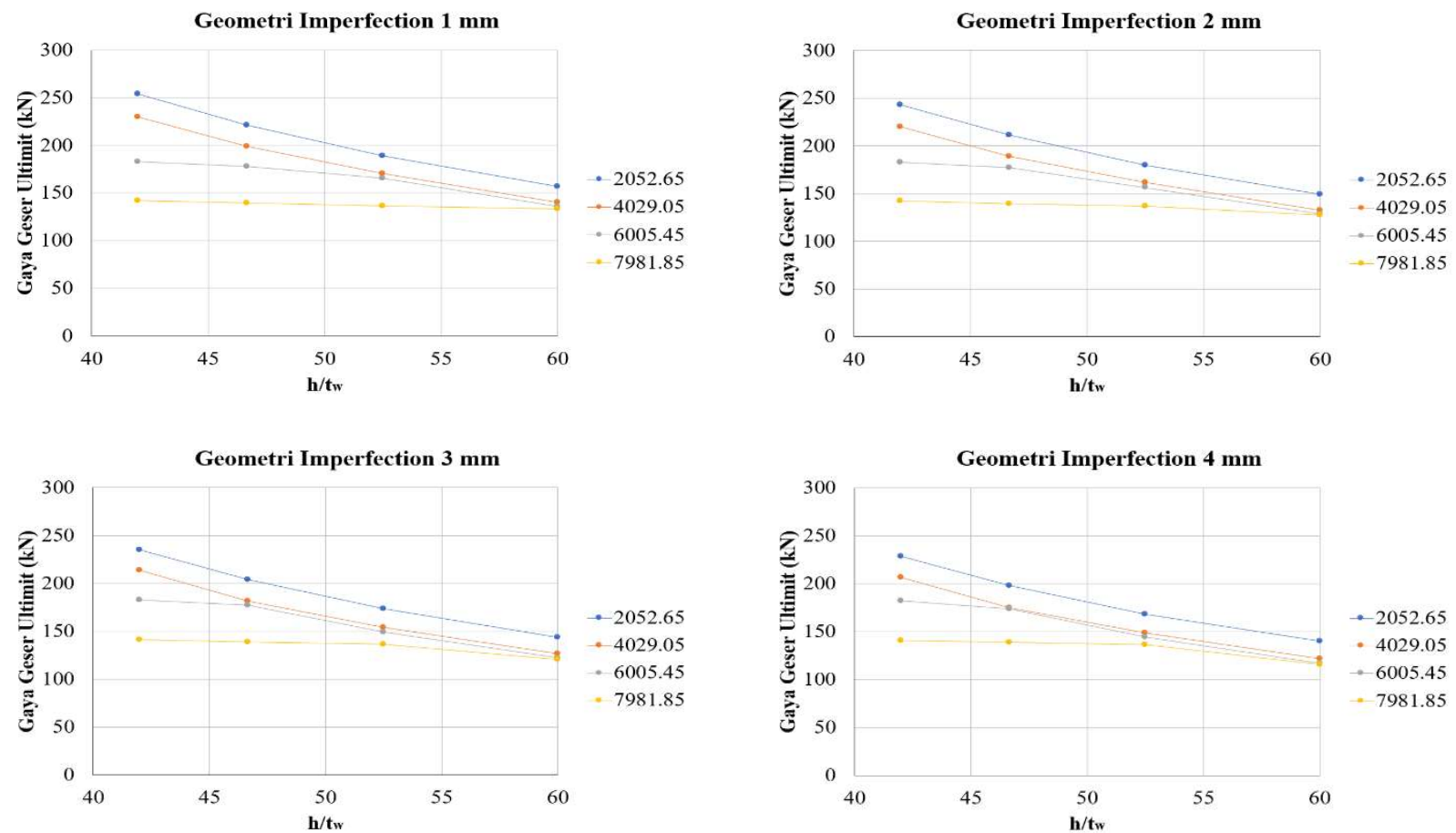

Gambar 14. Grafik Hubungan Gaya Geser Ultimit dan Rasio $h / t_{\mathrm{w}}$ pada Balok Kastela HC 450x300 untuk Geometri Imperfection 1, 2, 3, dan $4 \mathrm{~mm}$ 
Tabel 3. Parameter $\mathrm{h} / \mathrm{t}_{\mathrm{w}}$, Panjang Bentang, Geometri Imperfection, dan Momen Lentur terhadap Gaya Geser Balok Kastela

\begin{tabular}{|c|c|c|c|c|c|}
\hline \multicolumn{6}{|c|}{ HC 450x300 } \\
\hline $\begin{array}{l}\text { Profil Balok } \\
\text { Kastela }\end{array}$ & $\begin{array}{c}\text { Rasio } \\
\mathrm{h} / \mathrm{t}_{\mathrm{w}}\end{array}$ & $\begin{array}{c}\text { Panjang } \\
\text { Bentang } \\
(\mathrm{mm})\end{array}$ & $\begin{array}{c}\text { Geometri } \\
\text { Imperfection } \\
(\mathrm{mm})\end{array}$ & $\begin{array}{c}\text { Gaya Geser } \\
(\mathrm{kN})\end{array}$ & $\begin{array}{l}\text { Momen Lentur } \\
\qquad(\mathrm{kNm})\end{array}$ \\
\hline \multirow{17}{*}{$\begin{array}{c}\mathrm{HC} \\
450 \times 300 \times 10 \times 15\end{array}$} & \multirow{17}{*}{42} & \multirow{4}{*}{2052,65} & 1 & 253,69 & 109,15 \\
\hline & & & 2 & 243,03 & 104,56 \\
\hline & & & 3 & 235,16 & 102,33 \\
\hline & & & 4 & 228,39 & 99,38 \\
\hline & & \multirow{5}{*}{4029,05} & 1 & 229,90 & 221,54 \\
\hline & & & 2 & 220,19 & 212,18 \\
\hline & & & 3 & 213,53 & 205,76 \\
\hline & & & 4 & 206,69 & 199,18 \\
\hline & & & 1 & 182,94 & 502,34 \\
\hline & & \multirow{3}{*}{6005,45} & 2 & 182,61 & 502,32 \\
\hline & & & 3 & 182,57 & 502,21 \\
\hline & & & 4 & 182,38 & 502,57 \\
\hline & & \multirow{4}{*}{7981,85} & 1 & 142,25 & 533,97 \\
\hline & & & 2 & 142,18 & 533,69 \\
\hline & & & 3 & 141,35 & 530,57 \\
\hline & & & 4 & 140,68 & 526,70 \\
\hline & & \multirow{4}{*}{2052,65} & 1 & 221,51 & 95,29 \\
\hline \multirow{15}{*}{$\begin{array}{c}\mathrm{HC} \\
450 \times 300 \times 9 \times 15\end{array}$} & \multirow{14}{*}{46,67} & & 2 & 211,45 & 64,46 \\
\hline & & & 3 & 203,86 & 88,71 \\
\hline & & & 4 & 197,96 & 89,06 \\
\hline & & \multirow{5}{*}{4029,05} & 1 & 199,25 & 192,00 \\
\hline & & & 2 & 189,29 & 182,40 \\
\hline & & & 3 & 181,76 & 175,15 \\
\hline & & & 4 & 175,09 & 167,86 \\
\hline & & & 1 & 178,22 & 429,78 \\
\hline & & \multirow{3}{*}{6005,45} & 2 & 177,47 & 427,97 \\
\hline & & & 3 & 177,54 & 428,15 \\
\hline & & & 4 & 173,81 & 362,76 \\
\hline & & \multirow{4}{*}{7981,85} & 1 & 139,40 & 476,68 \\
\hline & & & 2 & 139,06 & 475,51 \\
\hline & & & 3 & 138,99 & 520,35 \\
\hline & \multirow{17}{*}{52,5} & & 4 & 139,11 & 520,79 \\
\hline \multirow{16}{*}{$\begin{array}{c}\mathrm{HC} \\
450 \times 300 \times 8 \times 15\end{array}$} & & \multirow{4}{*}{2052,65} & 1 & 189,23 & 81,41 \\
\hline & & & 2 & 179,98 & 77,43 \\
\hline & & & 3 & 173,57 & 75,52 \\
\hline & & & 4 & 168,34 & 73,25 \\
\hline & & \multirow{5}{*}{4029,05} & 1 & 170,41 & 185,58 \\
\hline & & & 2 & 161,42 & 176,59 \\
\hline & & & 3 & 154,28 & 168,77 \\
\hline & & & 4 & 148,79 & 162,78 \\
\hline & & & 1 & 165,40 & 289,09 \\
\hline & & \multirow{3}{*}{6005,45} & 2 & 156,37 & 274,07 \\
\hline & & & 3 & 149,56 & 262,88 \\
\hline & & & 4 & 144,41 & 253,82 \\
\hline & & \multirow{4}{*}{7981,85} & 1 & 136,75 & 465,58 \\
\hline & & & 2 & 136,69 & 465,39 \\
\hline & & & 3 & 136,34 & 464,19 \\
\hline & & & 4 & 136,39 & 420,11 \\
\hline
\end{tabular}


Tabel 3. Parameter $\mathrm{h} / \mathrm{t}_{\mathrm{w}}$, Panjang Bentang, Geometri Imperfection, dan Momen Lentur terhadap Gaya Geser Balok Kastela

\begin{tabular}{|c|c|c|c|c|c|}
\hline \multicolumn{6}{|c|}{ HC 450x300 (Lanjutan) } \\
\hline \multirow{16}{*}{$\begin{array}{c}\mathrm{HC} \\
450 \times 300 \times 7 \times 15\end{array}$} & \multirow{16}{*}{60} & \multirow{4}{*}{2052,65} & 1 & 156,86 & 67,49 \\
\hline & & & 2 & 149,32 & 64,24 \\
\hline & & & 3 & 143,79 & 62,57 \\
\hline & & & 4 & 139,94 & 60,89 \\
\hline & & \multirow{4}{*}{4029,05} & 1 & 140,29 & 152,78 \\
\hline & & & 2 & 132,51 & 144,95 \\
\hline & & & 3 & 126,67 & 138,57 \\
\hline & & & 4 & 121,79 & 133,23 \\
\hline & & \multirow{4}{*}{6005,45} & 1 & 135,95 & 238,29 \\
\hline & & & 2 & 128,47 & 225,17 \\
\hline & & & 3 & 122,45 & 215,22 \\
\hline & & & 4 & 116,95 & 205,55 \\
\hline & & \multirow{4}{*}{7981,85} & 1 & 133,37 & 366,21 \\
\hline & & & 2 & 127,19 & 307,36 \\
\hline & & & 3 & 120,89 & 292,13 \\
\hline & & & 4 & 115,89 & 280,05 \\
\hline
\end{tabular}

Tabel 4. Parameter $\mathrm{h} / \mathrm{t}_{\mathrm{w}}$, Panjang Bentang, Geometri Imperfection, dan Momen Lentur terhadap Gaya Geser Balok Kastela

\begin{tabular}{|c|c|c|c|c|c|}
\hline \multicolumn{6}{|c|}{ HC $600 \times 200$} \\
\hline $\begin{array}{c}\text { Profil Balok } \\
\text { Kastela }\end{array}$ & $\begin{array}{c}\text { Rasio } \\
\mathrm{h} / \mathrm{t}_{\mathrm{w}}\end{array}$ & $\begin{array}{c}\text { Panjang } \\
\text { Bentang } \\
(\mathrm{mm})\end{array}$ & $\begin{array}{c}\text { Geometri } \\
\text { Imperfection } \\
(\mathrm{mm})\end{array}$ & $\begin{array}{c}\text { Gaya Geser } \\
(\mathrm{kN})\end{array}$ & $\begin{array}{l}\text { Momen Lentur } \\
(\mathrm{kNm})\end{array}$ \\
\hline \multirow{16}{*}{$\begin{array}{c}\mathrm{HC} \\
600 \times 200 \times 8 \times 13\end{array}$} & \multirow{15}{*}{71,75} & \multirow{4}{*}{1850,85} & 1 & 220,99 & 87,96 \\
\hline & & & 2 & 210,54 & 84,56 \\
\hline & & & 3 & 209,27 & 84,05 \\
\hline & & & 4 & 208,84 & 83,88 \\
\hline & & \multirow{5}{*}{3600,45} & 1 & 200,43 & 203,82 \\
\hline & & & 2 & 190,96 & 195,16 \\
\hline & & & 3 & 184,29 & 188,34 \\
\hline & & & 4 & 178,49 & 182,42 \\
\hline & & & 1 & 158,74 & 449,68 \\
\hline & & \multirow{3}{*}{6224,85} & 2 & 157,57 & 446,38 \\
\hline & & & 3 & 157,13 & 445,12 \\
\hline & & & 4 & 156,58 & 443,58 \\
\hline & & \multirow{4}{*}{7974,45} & 1 & 128,45 & 476,26 \\
\hline & & & 2 & 127,69 & 474,11 \\
\hline & & & 3 & 127,17 & 472,17 \\
\hline & \multirow{17}{*}{82} & & 4 & 126,84 & 470,94 \\
\hline \multirow{16}{*}{$\begin{array}{c}\mathrm{HC} \\
600 \times 200 \times 7 \times 13\end{array}$} & & \multirow{4}{*}{1850,85} & 1 & 180,68 & 70,72 \\
\hline & & & 2 & 176,74 & 70,99 \\
\hline & & & 3 & 175,66 & 70,55 \\
\hline & & & 4 & 175,29 & 70,41 \\
\hline & & \multirow{5}{*}{3600,45} & 1 & 163,43 & 167,03 \\
\hline & & & 2 & 154,89 & 158,31 \\
\hline & & & 3 & 148,54 & 152,57 \\
\hline & & & 4 & 143,98 & 147,88 \\
\hline & & & 1 & 147,04 & 416,54 \\
\hline & & \multirow{3}{*}{6224,85} & 2 & 144,39 & 275,36 \\
\hline & & & 3 & 138,46 & 263,35 \\
\hline & & & 4 & 132,91 & 252,78 \\
\hline & & \multirow{4}{*}{7974,45} & 1 & 120,50 & 446,79 \\
\hline & & & 2 & 119,99 & 445,52 \\
\hline & & & 3 & 119,46 & 443,53 \\
\hline & & & 4 & 119,45 & 443,48 \\
\hline
\end{tabular}


Tabel 4. Parameter $\mathrm{h} / \mathrm{t}_{\mathrm{w}}$, Panjang Bentang, Geometri Imperfection, dan Momen Lentur terhadap Gaya Geser Balok Kastela

\begin{tabular}{|c|c|c|c|c|c|}
\hline \multicolumn{6}{|c|}{ HC 600x200 (Lanjutan) } \\
\hline \multirow{16}{*}{$\begin{array}{c}\mathrm{HC} \\
600 \times 200 \times 6 \times 13\end{array}$} & \multirow{16}{*}{95,67} & \multirow{4}{*}{1850,85} & 1 & 145,22 & 58,33 \\
\hline & & & 2 & 143,98 & 57,83 \\
\hline & & & 3 & 143,36 & 57,58 \\
\hline & & & 4 & 143,26 & 56,81 \\
\hline & & \multirow{5}{*}{3600,45} & 1 & 124,88 & 128,27 \\
\hline & & & 2 & 118,42 & 98,15 \\
\hline & & & 3 & 114,69 & 94,48 \\
\hline & & & 4 & 111,36 & 91,73 \\
\hline & & & 1 & 116,66 & 222,47 \\
\hline & & \multirow{3}{*}{6224,85} & 2 & 108,96 & 207,79 \\
\hline & & & 3 & 103,05 & 150,92 \\
\hline & & & 4 & 97,89 & 143,87 \\
\hline & & \multirow{4}{*}{7974,45} & 1 & 111,76 & 311,46 \\
\hline & & & 2 & 107,15 & 251,21 \\
\hline & & & 3 & 101,67 & 238,36 \\
\hline & & & 4 & 96,76 & 226,34 \\
\hline \multirow{16}{*}{$\begin{array}{c}\mathrm{HC} \\
600 \times 200 \times 5 \times 13\end{array}$} & \multirow{16}{*}{114,8} & \multirow{4}{*}{1850,85} & 1 & 113,37 & 44,96 \\
\hline & & & 2 & 112,43 & 44,58 \\
\hline & & & 3 & 112,42 & 44,58 \\
\hline & & & 4 & 112,21 & 44,49 \\
\hline & & \multirow{5}{*}{3600,45} & 1 & 88,23 & 73,13 \\
\hline & & & 2 & 84,85 & 70,33 \\
\hline & & & 3 & 83,43 & 69,15 \\
\hline & & & 4 & 81,80 & 67,79 \\
\hline & & & 1 & 79,66 & 117,08 \\
\hline & & \multirow{3}{*}{6224,85} & 2 & 76,16 & 111,54 \\
\hline & & & 3 & 72,23 & 105,78 \\
\hline & & & 4 & 70,58 & 103,37 \\
\hline & & \multirow{4}{*}{7974,45} & 1 & 77,55 & 181,41 \\
\hline & & & 2 & 73,56 & 139,91 \\
\hline & & & 3 & 70,59 & 134,27 \\
\hline & & & 4 & 68,19 & 130,04 \\
\hline
\end{tabular}

Parameter yang mempengaruhi besarnya gaya geser kritis web adalah tegangan leleh material baja $\left(\mathrm{F}_{\mathrm{y}}\right)$, tinggi profil balok kastela $(\mathrm{d})$, tebal web $\left(\mathrm{t}_{\mathrm{w}}\right)$, dan momen lentur. Untuk mendapatkan persamaan dalam menghitung gaya geser kritis, digunakan persamaan (1) dimana $\mathrm{C}$ adalah koefisien kekuatan geser yang merupakan fungsi dari imperfection $/ \mathrm{h}$, rasio $\mathrm{h} / \mathrm{t}_{\mathrm{w}}$, dan rasio $\mathrm{M} /\left(\mathrm{F}_{\mathrm{y}} \mathrm{dt}_{\mathrm{w}} \mathrm{h}_{0}\right)$. Variabel $\mathrm{h}_{0}$ adalah tinggi web yang dihitung dari jarak antara tengah flens atas dan flens bawah.

$V_{c r}=0,6 F_{y} d t_{w} C$

Untuk mendapatkan persamaan untuk koefisien kekuatan geser, digunakan data $\mathrm{V}_{\text {cr }}$ hasil analisis menggunakan ADINA 9.5 dan nilai $\mathrm{C}$ untuk data tersebut dihitung dengan menggunakan persamaan 2 .

$C=\frac{V_{c r}}{0,6 F_{y} d t_{w}}$

Setelah data koefisien kekuatan geser didapat, kemudian data tersebut diregresi untuk menghasilkan formulasi terhadap koefisien kekuatan geser (C). Hasil analisis regresi tersebut adalah persamaan 3 yang digunakan dalam penelitian ini.

$$
\begin{aligned}
C= & 0,493-3,717\left(\frac{\text { imperfection }}{h}\right)-0,00236\left(\frac{h}{t_{w}}\right)- \\
& 0,11023\left(\frac{M}{F_{y} d t_{w} h_{0}}\right)
\end{aligned}
$$

Koefisien kekuatan geser (C) dapat diketahui dengan memasukkan parameter yang mempengaruhi gaya geser tersebut. Nilai $\mathrm{C}$ yang didapat hanya berlaku untuk $\mathrm{E} / \mathrm{F}_{\mathrm{y}}$ tertentu yaitu modulus elastisitas baja sebesar $200 \mathrm{GPa}$ dan tegangan leleh material baja sebesar $250 \mathrm{MPa}$. Setelah persamaan regresi berupa koefisien kekuatan geser (C) telah diperoleh, kemudian dilakukan perbandingan mengenai perhitungan gaya geser kritis menggunakan koefisien kekuatan geser terhadap perhitungan gaya geser kritis berdasarkan AISC Design Guide nomor 31. Hasil perbandingan gaya geser tersebut dapat dilihat pada Tabel 5 dan Tabel 6. Perbandingan ini dilakukan pada salah satu contoh profil balok kastela yaitu HC 600×200 dengan tebal web $5 \mathrm{~mm}$ 
terhadap panjang bentang balok 2 dan 8 meter. Nilai momen plastis dihitung terlebih dahulu dengan persamaan 4 sebelum menghitung kekuatan geser kritis.

$M_{p}=0,25 t_{w}(e+2 b)^{2} F_{y}$

Nilai momen plastis yang didapat sebesar $35,312 \mathrm{kNm}$ dengan nilai e/ $\mathrm{t}_{\mathrm{w}}$ adalah 20,25 dan sudut lubang bukaan web sebesar 60 derajat. Variabel e adalah jarak bersih antar bukaan web dan variabel b adalah panjang sisi miring bukaan web. Oleh karena itu, nilai momen kritis dari tekuk lateral pos web dapat dihitung berdasarkan sudut lubang bukaan web dan rasio e $/ \mathrm{t}_{\mathrm{w}}$ yang dapat dihitung dengan persamaan 5 .

$M_{\text {ocr }}=\left(1,96(0,699)^{\frac{2 h_{t o p}}{e}}\right) M_{p}$

Nilai momen kritis yang dihitung adalah sebesar $16,523 \mathrm{kNm}$ sehingga nilai gaya geser horizontal yang diperoleh dalam tekuk pos web dapat menggunakan persamaan 6 .

$V_{r h}=\frac{M_{o c r}}{h_{\text {top }}}$

Nilai gaya geser horizontal yang didapat adalah sebesar $81,594 \mathrm{kN}$. Variabel $\mathrm{h}_{\text {top }}$ adalah tinggi setengah lubang bukaan web bagian atas. Dari persamaan AISC Design Guide nomor 31 tersebut, didapatkan persamaan untuk mencari kekuatan geser kritis pada pos web balok kastela yang dapat dilihat pada persamaan 7 .

$V_{c r}=\frac{V_{r h} d_{e f f e c}}{S}$

Nilai geser kritis yang didapat sebesar 97,877 kN dengan variabel $\mathrm{d}_{\text {effec }}$ adalah jarak antara titik berat penampang $\mathrm{T}$ web atas dan bawah. Variabel $\mathrm{S}$ adalah jarak antar tengah bukaan web.

Gaya geser kritis tersebut bernilai sama untuk panjang bentang balok 2 dan 8 meter. Sedangkan gaya geser kritis berdasarkan koefisien kekuatan geser yang berasal dari persamaan regresi yaitu persamaan 1 memiliki nilai masingmasing terhadap panjang bentang balok 2 dan 8 meter. Untuk bentang balok 2 meter, nilai gaya geser kritis yang didapat adalah 91,953 kN dengan selisih nilai gaya geser kritis terhadap perhitungan menggunakan design guide adalah sebesar $6,05 \%$. Sedangkan untuk bentang balok 8 meter, nilai gaya geser kritis yang didapat adalah $76,578 \mathrm{kN}$ dengan selisih nilai gaya geser kritis terhadap perhitungan menggunakan design guide adalah sebesar 21,761\%.

Dari perhitungan gaya geser kritis berdasarkan koefisien kekuatan geser, besarnya momen lentur akan mengurangi besarnya gaya geser kritis pada balok kastela akibat nilai $\mathrm{C}$ yang semakin kecil. Sedangkan perhitungan gaya geser kritis berdasarkan AISC Design Guide nomor 31, hasil gaya geser kritis yang diperoleh bernilai konstan untuk berbagai variasi bentang balok kastela. Oleh karena itu, perhitungan gaya geser kritis menggunakan koefisien kekuatan geser memiliki hasil yang berbeda dengan perhitungan gaya geser kritis berdasarkan design guide. Persen beda yang dihasilkan juga semakin rendah diakibatkan nilai gaya geser kritis dari program ADINA dan regresi yang lebih besar daripada gaya geser kritis AISC Design Guide mengalami penurunan akibat bentang balok yang semakin panjang sampai mendekati gaya geser kritis AISC Design Guide yang konstan. Hal ini dapat dilihat dari selisih nilai gaya geser kritis yang bervariatif untuk profil balok HC 600x200 berkisar di antara 0,29\% sampai dengan $31,02 \%$. Sedangkan profil balok kastela HC 450x300 berkisar di antara 13,36\% sampai dengan 87,74\%. Selain itu, selisih gaya geser kritis dari program ADINA ter hadap gaya geser kritis berdasarkan design guide juga bervariatif untuk profil balok HC 600x200 berkisar di antara $0,46 \%$ sampai dengan $32,53 \%$. Sedangkan untuk profil balok HC 450x300 berkisar di antara 8,56\% sampai dengan $95,76 \%$.

\section{Simpulan}

Berdasarkan studi numerikal mengenai perilaku tekuk web yang ditinjau dari segi hubungan gaya geser kritis terhadap rasio $\mathrm{h} / \mathrm{t}_{\mathrm{w}}$, ketidaksempurnaan geometri, dan besar momen lentur yang terjadi pada balok kastela untuk mendapatkan persamaan gaya geser, dapat disimpulkan bahwa:

1. Semakin besar momen lentur yang terjadi maka gaya geser yang dapat diterima dan peralihan lateral maksimum yang terjadi semakin rendah.

2. Semakin besarnya nilai geometri imperfection maka semakin kecil nilai gaya geser yang diterima balok kastela.

3. Semakin tebal web balok kastela maka semakin besar gaya geser yang dapat diterima akibat beban ultimit yang dipikul semakin besar.

4. Gaya geser kritis web balok kastela dengan besaran geometri lubang berdasarkan tabel penampang Gunung Garuda yang dipilih dapat dihitung dengan persamaan (1) dengan koefisien kekuatan geser (C) dihitung dengan persamaan (3).

\section{DAFTAR PUSTAKA}

[1] M. R. Wakchaure and A. V. Sagade, "Finite Element Analysis of Castellated Steel Beam," International Journal of Engineering and Innovative Technology (IJEIT), vol.2, no. 1, p. 365 - 372, 2012.

[2] ENV 1993-1-1 (2005) Eurocode 3, "Design of Steel Structures-Part 1-1: General Rules and Rules for Buildings. Amendment A2 of Eurocode 3: Annex N Opening in Webs.” British Standards Institution, 2011. 
[3] M. R. Soltani, A. Bouchair, and M. Mimoune, "Nonlinear FE Analysis of the Ultimate Behavior of Steel Castellated Beams," Journal of Constructional Steel Research, vol. 70, p. 101 - 114, 2012.

[4] H. Deng, W. L. Pu, T. L. Li, and D. Chen, "Analysis on Behavior of Web Buckling of Hexagonal Castellated Beams with Transverse Stiffeners Under Uniform Loads," $5^{\text {th }}$ International Conference on Civil Engineering and Transportation (ICCET), p. $380-384,2015$.

[5] P. Pourbehi and A. Pirmoz, "Shear Response of Castellated Steel Beams," International Journal of Steel Structures, vol. 15, no. 2, p. 389 - 399, 2015.

[6] F. Menkulasi, C. D. Moen, M. R. Eatherton, and D. Kuruppuarachchi, "Investigation of Web Post Compression Buckling Limit State and Stiffener
Requirements in Castellated Beams," Engineering Journal, AISC, First Quarter 2017, vol. 54, no. 1, p. $21-43,2017$.

[7] W. Ji, L. Jia, Y. Wang, and C. Chen, "Experimental Study of Local Buckling of Castellated Steel Beams Under Pure Bending," IOP Conference Series: Material Science and Engineering, vol. 392, no. 2, p. $1-6,2018$.

[8] American Institute of Steel Construction (AISC), "Steel Design Guide 31 - Castellated and Cellular Beam Design.” Lawrence, Kansas, 2016.

[9] American Institute of Steel Construction (AISC), "Specification for Structural Steel Buildings (AISC 360-16).” Chicago, Illinois, 2016.

Tabel 5. Hasil Perbandingan Gaya Geser Kritis Balok Kastela HC 450x300

\begin{tabular}{|c|c|c|c|c|c|c|c|}
\hline $\begin{array}{c}\text { Profil Balok } \\
\text { Kastela }\end{array}$ & $\begin{array}{c}\text { Panjang } \\
\text { Bentang } \\
(\mathrm{mm})\end{array}$ & $\begin{array}{c}\text { Geometri } \\
\text { Imperfection } \\
(\mathrm{mm})\end{array}$ & $\begin{array}{c}\text { Gaya } \\
\text { Geser } \\
\text { ADINA } \\
(\mathrm{kN})\end{array}$ & $\begin{array}{c}\text { Gaya } \\
\text { Geser } \\
\text { Regresi } \\
(\mathrm{kN})\end{array}$ & $\begin{array}{l}\text { Gaya Geser } \\
\text { AISC } \\
\text { Design } \\
\text { Guide (kN) }\end{array}$ & $\begin{array}{c}\text { Selisih } \\
\text { Gaya Geser } \\
\text { Regresi vs } \\
\text { AISC }(\%)\end{array}$ & $\begin{array}{c}\text { Selisih } \\
\text { Gaya Geser } \\
\text { ADINA vs } \\
\text { AISC (\%) }\end{array}$ \\
\hline \multirow{16}{*}{$\begin{array}{c}\mathrm{HC} \\
450 \times 300 \times 10 \times 15\end{array}$} & \multirow{4}{*}{2052,65} & 1 & 253,69 & 243,30 & \multirow{16}{*}{129,59} & 87,74 & 95,76 \\
\hline & & 2 & 243,03 & 238,02 & & 83,67 & 87,53 \\
\hline & & 3 & 235,16 & 232,39 & & 79,32 & 81,46 \\
\hline & & 4 & 228,39 & 226,87 & & 75,06 & 76,23 \\
\hline & \multirow{4}{*}{4029,05} & 1 & 229,90 & 226,21 & & 74,55 & 77,40 \\
\hline & & 2 & 220,19 & 221,66 & & 71,04 & 69,91 \\
\hline & & 3 & 213,53 & 216,66 & & 67,18 & 64,76 \\
\hline & & 4 & 206,69 & 211,69 & & 63,35 & 59,49 \\
\hline & \multirow{4}{*}{6005,45} & 1 & 182,94 & 183,52 & & 41,61 & 41,16 \\
\hline & & 2 & 182,61 & 177,55 & & 37,00 & 40,91 \\
\hline & & 3 & 182,57 & 171,59 & & 32,40 & 40,88 \\
\hline & & 4 & 182,38 & 165,56 & & 27,75 & 40,73 \\
\hline & \multirow{4}{*}{7981,85} & 1 & 142.25 & 178,71 & & 37,89 & 9,77 \\
\hline & & 2 & 142.18 & 172,78 & & 33,32 & 9,71 \\
\hline & & 3 & 141.35 & 167,28 & & 29,08 & 9,07 \\
\hline & & 4 & 140.68 & 161,89 & & 24,92 & 8,56 \\
\hline \multirow{16}{*}{$\begin{array}{c}\mathrm{HC} \\
450 \times 300 \times 9 \times 15\end{array}$} & \multirow{4}{*}{2052,65} & 1 & 221,51 & 212,73 & \multirow{16}{*}{115,13} & 84,76 & 92,39 \\
\hline & & 2 & 211,45 & 212,04 & & 84,17 & 83,65 \\
\hline & & 3 & 203,86 & 202,98 & & 76,29 & 77,06 \\
\hline & & 4 & 197,96 & 197,55 & & 71,58 & 71,93 \\
\hline & \multirow{4}{*}{4029,05} & 1 & 199,25 & 198,02 & & 71,99 & 73,06 \\
\hline & & 2 & 189,29 & 194,11 & & 68,59 & 64,41 \\
\hline & & 3 & 181,76 & 189,83 & & 64,88 & 57,87 \\
\hline & & 4 & 175,09 & 185,56 & & 61,17 & 52,07 \\
\hline & \multirow{4}{*}{6005,45} & 1 & 178,22 & 161,87 & & 40,59 & 54,79 \\
\hline & & 2 & 177,47 & 156,77 & & 36,16 & 54,14 \\
\hline & & 3 & 177,54 & 151,37 & & 31,47 & 54,20 \\
\hline & & 4 & 173,81 & 155,93 & & 35,43 & 50,97 \\
\hline & \multirow{4}{*}{7981,85} & 1 & 139,40 & 154,74 & & 34,39 & 21,08 \\
\hline & & 2 & 139,06 & 149,54 & & 29,88 & 20,78 \\
\hline & & 3 & 138,99 & 137,35 & & 19,29 & 20,72 \\
\hline & & 4 & 139,11 & 131,91 & & 14,57 & 20,82 \\
\hline
\end{tabular}


Tabel 5. Hasil Perbandingan Gaya Geser Kritis Balok Kastela HC 450x300 (lanjutan)

\begin{tabular}{|c|c|c|c|c|c|c|c|}
\hline \multirow{16}{*}{$\begin{array}{c}\mathrm{HC} \\
450 \times 300 \times 8 \times 15\end{array}$} & \multirow{4}{*}{2052,65} & 1 & 189,23 & 182,16 & \multirow{16}{*}{100,92} & 80,50 & 87,51 \\
\hline & & 2 & 179,98 & 177,98 & & 76,37 & 78,34 \\
\hline & & 3 & 173,57 & 173,49 & & 71,92 & 71,99 \\
\hline & & 4 & 168,34 & 169,06 & & 67,53 & 66,81 \\
\hline & \multirow{5}{*}{4029,05} & 1 & 170,41 & 166,32 & & 64,81 & 68,86 \\
\hline & & 2 & 161,42 & 162,91 & & 61,43 & 59,96 \\
\hline & & 3 & 154,28 & 159,32 & & 57,87 & 52,88 \\
\hline & & 4 & 148,79 & 155,45 & & 54,04 & 47,45 \\
\hline & & 1 & 165,40 & 150,58 & & 49,21 & 63,90 \\
\hline & \multirow{4}{*}{6005,45} & 2 & 156,37 & 148,09 & & 46,74 & 54,95 \\
\hline & & 3 & 149,56 & 145,01 & & 43,69 & 48,21 \\
\hline & & 4 & 144,41 & 141,61 & & 40,32 & 43,09 \\
\hline & & 1 & 136,75 & 123,75 & & 22,62 & 35,51 \\
\hline & \multirow{3}{*}{7981,85} & 2 & 136,69 & 118,99 & & 17,92 & 35,45 \\
\hline & & 3 & 136,34 & 114,40 & & 13,36 & 35,10 \\
\hline & & 4 & 136,39 & 116,32 & & 15,27 & 35,15 \\
\hline \multirow{16}{*}{$\begin{array}{c}\mathrm{HC} \\
450 \times 300 \times 7 \times 15\end{array}$} & \multirow{4}{*}{2052,65} & 1 & 156,86 & 151,59 & \multirow{16}{*}{86,97} & 74,31 & 80,37 \\
\hline & & 2 & 149,32 & 147,91 & & 70,07 & 71,70 \\
\hline & & 3 & 143,79 & 143,98 & & 65,56 & 65,34 \\
\hline & & 4 & 139,94 & 140,05 & & 61,04 & 60,91 \\
\hline & \multirow{5}{*}{4029,05} & 1 & 140,29 & 138,63 & & 59,40 & 61,31 \\
\hline & & 2 & 132,51 & 135,63 & & 55,96 & 52,37 \\
\hline & & 3 & 126,67 & 132,42 & & 52,27 & 45,66 \\
\hline & & 4 & 121,79 & 129,05 & & 48,39 & 40,05 \\
\hline & & 1 & 135,95 & 125,63 & & 44,45 & 56,33 \\
\hline & \multirow{3}{*}{6005,45} & 2 & 128,47 & 123,44 & & 41,94 & 47,72 \\
\hline & & 3 & 122,45 & 120,77 & & 38,87 & 40,79 \\
\hline & & 4 & 116,95 & 118,06 & & 35,75 & 34,47 \\
\hline & \multirow{4}{*}{7981,85} & 1 & 133,37 & 106,17 & & 22,09 & 53,36 \\
\hline & & 2 & 127,19 & 110,94 & & 27,57 & 46,26 \\
\hline & & 3 & 120,89 & 109,08 & & 25,42 & 39,01 \\
\hline & & 4 & 115,89 & 106,73 & & 22,73 & 33,26 \\
\hline
\end{tabular}

Tabel 6. Hasil Perbandingan Gaya Geser Kritis Balok Kastela HC 600x200

\begin{tabular}{cccccccc}
\hline $\begin{array}{c}\text { Profil Balok } \\
\text { Kastela }\end{array}$ & $\begin{array}{c}\text { Panjang } \\
\text { Bentang } \\
(\mathrm{mm})\end{array}$ & $\begin{array}{c}\text { Geometri } \\
\text { Imperfection } \\
(\mathrm{mm})\end{array}$ & $\begin{array}{c}\text { Gaya } \\
\text { Geser } \\
\text { ADINA } \\
(\mathrm{kN})\end{array}$ & $\begin{array}{c}\text { Gaya } \\
\text { Geser } \\
\text { Regresi } \\
(\mathrm{kN})\end{array}$ & $\begin{array}{c}\text { Gaya Geser } \\
\text { AISC } \\
\text { Design } \\
\text { Guide }(\mathrm{kN})\end{array}$ & $\begin{array}{c}\text { Selisih } \\
\text { Gaya Geser } \\
\text { Regresi vs } \\
\text { AISC (\%) }\end{array}$ & $\begin{array}{c}\text { Selisih } \\
\text { Gaya Geser } \\
\text { ADINA vs } \\
\text { AISC (\%) }\end{array}$ \\
\hline & & 1 & 113,37 & 91,95 & & 6,05 & 15,83 \\
& \multirow{2}{*}{1850.85} & 2 & 112,43 & 89,08 & 8,99 & 14,87 \\
& & 3 & 112,42 & 86,17 & 11,97 & 14,86 \\
& & 4 & 112,21 & 83,26 & 14,93 & 14,64 \\
HC & 1 & 88,23 & 88,78 & & 9,29 & 9,86 \\
& & 2 & 84,85 & 86,18 & & 11,95 & 13,31 \\
& & 3 & 83,43 & 83,39 & & 14,79 & 14,76 \\
& & 4 & 81,80 & 80,64 & 97,88 & 17,61 & 16,43 \\
& & 1 & 79,66 & 83,83 & & 14,35 & 18,61 \\
& & 2 & 76,16 & 81,54 & & 16,69 & 22,19 \\
& & 3 & 72,23 & 79,27 & & 21,71 & 27,89 \\
& & 4 & 70,58 & 76,63 & & 21,76 & 20,77 \\
& & 1 & 77,55 & 76,58 & & 19,96 & 24,85 \\
& & 2 & 73,56 & 78,34 & & 22,29 & 27,87 \\
& & 3 & 70,59 & 76,06 & & 24,78 & 30,33 \\
\hline
\end{tabular}


Tabel 6. Hasil Perbandingan Gaya Geser Kritis Balok Kastela HC 600x200 (lanjutan)

\begin{tabular}{|c|c|c|c|c|c|c|c|}
\hline $\begin{array}{l}\text { Profil Balok } \\
\text { Kastela }\end{array}$ & $\begin{array}{c}\text { Panjang } \\
\text { Bentang } \\
(\mathrm{mm})\end{array}$ & $\begin{array}{c}\text { Geometri } \\
\text { Imperfection } \\
(\mathrm{mm})\end{array}$ & $\begin{array}{c}\text { Gaya } \\
\text { Geser } \\
\text { ADINA } \\
(\mathrm{kN})\end{array}$ & $\begin{array}{c}\text { Gaya } \\
\text { Geser } \\
\text { Regresi } \\
(\mathrm{kN})\end{array}$ & $\begin{array}{c}\text { Gaya Geser } \\
\text { AISC } \\
\text { Design } \\
\text { Guide }(\mathrm{kN}) \\
\end{array}$ & $\begin{array}{c}\text { Selisih } \\
\text { Gaya Geser } \\
\text { Regresi vs } \\
\text { AISC (\%) }\end{array}$ & $\begin{array}{c}\text { Selisih } \\
\text { Gaya Geser } \\
\text { ADINA vs } \\
\text { AISC (\%) }\end{array}$ \\
\hline \multirow{16}{*}{$\begin{array}{c}\mathrm{HC} \\
600 \times 200 \times 8 \times 13\end{array}$} & \multirow{4}{*}{1850,85} & 1 & 220,99 & 218,47 & \multirow{16}{*}{166,75} & 31,02 & 32,53 \\
\hline & & 2 & 210,54 & 214,19 & & 28,45 & 26,26 \\
\hline & & 3 & 209,27 & 209,58 & & 25,69 & 25,49 \\
\hline & & 4 & 208,84 & 204,94 & & 22,91 & 25,24 \\
\hline & \multirow{4}{*}{3600,45} & 1 & 200,43 & 205,42 & & 23,19 & 20,19 \\
\hline & & 2 & 190,96 & 201,73 & & 20,98 & 14,52 \\
\hline & & 3 & 184,29 & 197,83 & & 18,64 & 10,52 \\
\hline & & 4 & 178,49 & 193,84 & & 16,25 & 7,04 \\
\hline & \multirow{4}{*}{6224,85} & 1 & 158,74 & 177,71 & & 6,58 & 4,81 \\
\hline & & 2 & 157,57 & 173,42 & & 4,00 & 5,51 \\
\hline & & 3 & 157,13 & 168,91 & & 1,29 & 5,77 \\
\hline & & 4 & 156,58 & 164,41 & & 1,40 & 6,09 \\
\hline & \multirow{4}{*}{7974,45} & 1 & 128,45 & 174,72 & & 4,78 & 22,97 \\
\hline & & 2 & 127,69 & 170,29 & & 2,13 & 23,42 \\
\hline & & 3 & 127,17 & 165,86 & & 0,54 & 23,73 \\
\hline & & 4 & 126,84 & 161,33 & & 3,25 & 23,93 \\
\hline \multirow{16}{*}{$\begin{array}{c}\mathrm{HC} \\
600 \times 200 \times 7 \times 13\end{array}$} & \multirow{4}{*}{1850,85} & 1 & 180,68 & 176,62 & \multirow{16}{*}{143,31} & 23,24 & 26,07 \\
\hline & & 2 & 176,74 & 172,51 & & 20,37 & 23,32 \\
\hline & & 3 & 175,66 & 168,48 & & 17,56 & 22,57 \\
\hline & & 4 & 175,29 & 164,42 & & 14,73 & 22,31 \\
\hline & \multirow{8}{*}{6224,85} & 1 & 163,43 & 165,77 & & 15,67 & 14,03 \\
\hline & & 2 & 154,89 & 162,68 & & 13,51 & 8,08 \\
\hline & & 3 & 148,54 & 159,24 & & 11,11 & 3,65 \\
\hline & & 4 & 143,98 & 155,69 & & 8,64 & 0,46 \\
\hline & & 1 & 147,04 & 137,66 & & 3,95 & 2,59 \\
\hline & & 2 & 144,39 & 149,49 & & 4,31 & 0,75 \\
\hline & & 3 & 138,46 & 146,76 & & 2,41 & 3,39 \\
\hline & & 4 & 132,91 & 143,87 & & 0,39 & 7,26 \\
\hline & \multirow{4}{*}{7974,45} & 1 & 120,50 & 134,25 & & 6,32 & 15,92 \\
\hline & & 2 & 119,99 & 130,32 & & 9,07 & 16,27 \\
\hline & & 3 & 119,46 & 126,46 & & 11,76 & 16,65 \\
\hline & & 4 & 119,45 & 122,39 & & 14,60 & 16,66 \\
\hline \multirow{16}{*}{$\begin{array}{c}\mathrm{HC} \\
600 \times 200 \times 6 \times 13\end{array}$} & \multirow{4}{*}{1850,85} & 1 & 145,22 & 134,23 & \multirow{16}{*}{120,33} & 11,56 & 20,69 \\
\hline & & 2 & 143,98 & 130,79 & & 8,69 & 19,66 \\
\hline & & 3 & 143,36 & 127,33 & & 5,82 & 19,14 \\
\hline & & 4 & 143,26 & 123,92 & & 2,98 & 19,06 \\
\hline & \multirow{8}{*}{6224,85} & 1 & 124,88 & 126,35 & & 5,01 & 3,78 \\
\hline & & 2 & 118,42 & 126,25 & & 4,92 & 1,58 \\
\hline & & 3 & 114,69 & 123,17 & & 2,36 & 4,68 \\
\hline & & 4 & 111,36 & 119,98 & & 0,29 & 7,45 \\
\hline & & 1 & 116,66 & 115,74 & & 3,81 & 3,05 \\
\hline & & 2 & 108,96 & 113,89 & & 5,34 & 9,44 \\
\hline & & 3 & 103,05 & 116,81 & & 2,93 & 14,36 \\
\hline & & 4 & 97,89 & 114,11 & & 5,17 & 18,64 \\
\hline & \multirow{4}{*}{7974,45} & 1 & 111,76 & 105,71 & & 12,14 & 7,12 \\
\hline & & 2 & 107,15 & 109,01 & & 9,41 & 10,95 \\
\hline & & 3 & 101,67 & 106,96 & & 11,11 & 15,50 \\
\hline & & 4 & 96,76 & 104,81 & & 12,89 & 19,59 \\
\hline
\end{tabular}

